p-ISSN: 2775-6025 ; e-ISSN: 2775-9296 DOI:10.32493

Jurnal Ilmiah Mahasiswa (JIMAWA)

Vol. 1, No. 1, Maret 2021 (19-28)

http://openjournal.unpam.ac.id/index.php/JMW/index

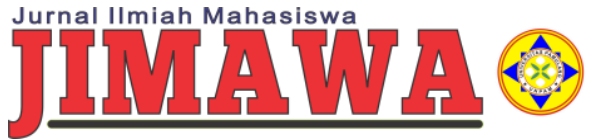

\title{
Pengaruh Gaya Kepemimpinan Dan Pelatihan Terhadap Produktivitas Kerja Karyawan Pada PT. Sumber Alfaria Trijaya, Tbk Area BSD Tangerang Selatan
}

\author{
Aldy Baihaqi ${ }^{1}$, Herry Suherman ${ }^{2 *}$ \\ ${ }^{1}$ Mahasiswa Manajemen (NIM.161010551346) ${ }^{1}$, Universitas Pemulang; aldybaihaqi95@ gmail.com \\ ${ }^{2}$ Fakultas Ekonomi, Universitas Pamulang; dosen01060@unpam.ac.id*
}

Received 09 Februari 2021| Revised 09 Maret 2021 | Accepted 25 Maret 2021

*Korespondensi Penulis

\begin{abstract}
Abstrak
Penelitian ini bertujuan untuk mengetahui pengaruh Gaya Kepemimpinan dan Pelatihan terhadap Produktivitas Kerja Karyawan baik secara parsial maupun simultan pada PT. Sumber Alfaria Trijaya, Tbk Area BSD Tangerang Selatan. Metode yang digunakan dalam penelitian ini adalah kuantitatif. Teknik analisis menggunakan analisis statistik dengan pengujian uji validitas, uji reliabilitas, uji asumsi klasik, analisis deskriptif, uji regresi linear sederhana, uji regresi linear berganda, uji koefisien korelasi, uji koefisien determinasi, uji t dan uji F. Populasi dalam penelitian ini adalah karyawan PT. Sumber Alfaria Trijaya, Tbk Area BSD Tangerang Selatan dengan sample jenuh sebanyak 85 responden. Hasil penelitian menunjukan bahwa gaya kepemimpinan dan pelatihan mempunyai konstribusi terhadap produktivitas kerja karyawan sebesar $44,4 \%$ dengan persamaan regresi linear berganda $\mathrm{Y}=17.722+$ $0.654 \mathrm{X}_{1}+0.035 \mathrm{X}_{2}$. Hasil pengujian pengaruh simultan diperoleh nilai nilai Fhitung $=32,806>$ nilai Ftabel $=3,11$, sehingga dapat disimpulkan bahwa terdapat pengaruh yang signifikan antara gaya kepemimpinan dan pelatihan terhadap produktivitas kerja karyawan PT. Sumber Alfaria Trijaya, Tbk area BSD Tangerang Selatan.
\end{abstract}

Kata Kunci : Gaya Kepemimpinan; Pelatihan; Produktivitas Kerja

\begin{abstract}
This study aims to determine the effect of Leadership Style and Training on Employee Productivity either partially or simultaneously at PT. Sumber Alfaria Trijaya, Tbk BSD Area, South Tangerang. The method used in this research is quantitative. The analysis technique uses statistical analysis with validity test, reliability test, classic assumption test, descriptive analysis, simple linear regression test, multiple linear regression test, correlation coefficient test, determination coefficient test, $t$ test and $F$ test. PT. Sumber Alfaria Trijaya, Tbk BSD Area, South Tangerang with a saturated sample of 85 respondents. The results showed that the leadership style and training contributed to the work productivity of employees by $44.4 \%$ with the multiple linear regression equation $Y=17.722+0.654 X 1+0.035 X 2$. The results of the simultaneous effect test obtained that the value of Fcount $=32.806>$ Ftable value $=3.11$, so it can be concluded that there is a significant influence between leadership style and training on employee work productivity of PT. Sumber Alfaria Trijaya, Tbk BSD area, South Tangerang..
\end{abstract}

Keywords : Leadership Style; Training; Work Productivity 


\section{PENDAHULUAN}

Perusahaan merupakan suatu organisasi produksi yang meggunakan dan mengkoordinir sumber - sumber ekonomi untuk memuaskan kebutuhan dengan cara yang menguntungkan. Aktivitas suatu perusahaan dalam pencapaian tujuan tersebut diperlukan pengelolaan faktorfaktor produksi yang terdiri dari sumber daya alam, sumber daya manusia, modal, bahan baku, mesin, teknologi. Perusahaan harus selalu memperhatikan keterkaitan antara faktor-faktor produksi tersebut, dengan demikian perusahaan dituntut untuk dapat mengelola dengan sebaikbaiknya terutama dalam bidang sumber daya manusia sehingga mampu bekerja lebih efektif dan efisien.

Sumber daya manusia dituntut untuk mampu mengatasi segala tantangan dan diharapkan mampu memanfaatkan peluang serta dapat memenuhi tuntutan kebutuhan, khususnya yang ada atau datang dari lingkungan kerjanya.

PT. Sumber Alfaria Trijaya, tbk Area BSD Tangerang Selatan adalah suatu perusahaan yang bergerak di bidang perdagangan dan jasa atau kata lainnya adalah (RITEL). Sumber daya manusia PT. Sumber Alfaria Trijaya, tbk area BSD Tangerang Selatan senantiasa selalu ingin mewujudkan kinerja yang terbaik dalam bidang ketersediaan barang dagang, penjualan, dan pelayanan. Dimulai dari perekrutan karyawan sampai dengan pelatihan kemudian bekerja, semua karyawan selalu dibekali peraturan oleh perusahaan, agar karyawan selalu menjalankan SOP perusahaan, sehingga karyawan mampu bekerja dengan rasa tanggung jawab yang tinggi dan mampu mempertanggung jawabkan hasil kerjanya kepada perusahaan. Dalam menjalankan tugas, setiap hari karyawan dihadapkan dengan beban tugas yang silih berganti dan semuanya harus dikerjakan sesuai target, tak jarang hal ini dapat menyebabkan karyawan mengalami tekanan dari pimpinan. Sikap pemimpin terkadang juga terlalu cuek dan jarang sekali menegur apabila ada karyawan yang tidak mentaati peraturan yang sudah ditetapkan perusahaan. Tekanan yang diberikan secara terus menerus kepada karyawan dapat menyebabkan karyawan merasa tidak nyaman dalam bekerja, sehingga produktivitas kerja pun dapat ikut menurun.

Gaya Kepemimpinan merupakan faktor penting dalam tercapainya tujuan suatu organisasi , karena gaya kepemimpinan menggambarkan kombinasi yang konsisten dari filsafah, keterampilan, sifat, dan sikap yang mendasari perilaku seseorang. Gaya kepemimpinan menunjukan secara langsung maupun tidak langsung tentang keyakinan seorang pemimpin terhadap kemampuan bawahannya. Artinya gaya kepemimpinan adalah perilaku dan strategi, sebagai hasil kombinasi dari filsafah, keterampilan, sifat, sikap, yang sering diterapkan seorang pemimpin ketika ia mencoba mempengaruhi kinerja bawahannya. Oleh sebab itu dibutuhkan seorang pemimpin yang mampu menjadi contoh teladan dan juga mengayomi bawahannya, supaya para bawahannya pun dapat meningkatkan produktivitas kerjanya. Karena keberhasilan suatu organisasi ditentukan oleh adanya komunikasi yang baik, komunikasi yang dimaksud adalah komunikasi antara karyawan dan pimpinan. Komunikasi yang baik adalah jalinan pengertian antara pihak yang satu dengan pihak yang lain sehingga apa yang dikomunikasikan dapat dimengerti, dipikirkan, dan dilaksanakan dengan baik. Sedangkan yang terjadi pada PT. Sumber Alfaria Trijaya, Tbk Area BSD Tangerang Selatan pemimpin seringkali miss komunikasi dengan karyawan dalam penyelesaian tugas. Pemimpin juga kurang berkonsultasi dengan karyawan sebelum mengambil suatu keputusan.

Berdasarkan penelitian awal yang saya lakukan pada PT. Sumber Alfaria Trijaya, Tbk Area BSD Tangerang Selatan terdapat penerapan indikator kepemimpinan yang sangat rendah terutama dalam hal kebiasaan. Pemimpin tidak dapat memberikan contoh yang baik dalam sikap disiplin terhadap waktu dangan selalu datang terlambat yang menyebabkan karyawan lain juga ikut 
menirunya. Dan pemimpin juga tidak menetapkan sanksi tegas kepda karyawan yang tidak tepat waktu, hal ini menyebabkan karyawan menjadi merasa tidak memiliki keharusan untuk datang sesuai jadwal yang sudah ditentukan. Dalam hal ini peneliti menduga ada beberapa penyebab kenapa pemimpin bersikap seperti itu terhadap bawahannya.

Tabel 1. Latar Belakang Pemimpin PT. Sumber Alfaria Trijaya, Tbk Area BSD Tangerang Selatan

\begin{tabular}{clr}
\hline Aspek & \multicolumn{1}{c}{ Kriteria } & Jumlah \\
\hline \multirow{2}{*}{ Usia } & $\begin{array}{l}\text { Rata - rata usia pemimpin pada PT. Sumber Alfaria Trijaya, Tbk Area } \\
\text { BSD Tangerang Selatan adalah berkisar 20 - 30 tahun }\end{array}$ & \multirow{2}{*}{ 31 orang } \\
\hline \multirow{3}{*}{ Pendidikan } & Pemimpin berlatar belakang pendidikan SLTA & 23 orang \\
\cline { 2 - 3 } & Pemimpin berlatar belakang pendidikan D3 & 5 orang \\
\cline { 2 - 3 } & Pemimpin berlatar belakang pendidikan S1 & 5 orang \\
\hline \multirow{2}{*}{ Lama Bekerja } & $\begin{array}{l}\text { Pemimpin pada PT. Sumber Alfaria Trijaya, Tbk Area BSD tangerang } \\
\end{array}$ & Selatan rata - rata sudah bekerja selama 4 - 7 tahun. \\
\hline
\end{tabular}

Sumber : PT. Sumber Alfaria Trijaya, Tbk Area BSD Tangerang Selatan (2020)

Dari tabel 1 dapat terlihat bahwa untuk rata - rata usia dari pemimpin pada PT. Sumber Alfaria Trijaya, Tbk Area BSD Tangerang Selatan adalah bersikar $20-30$ tahun, yang dapat dibilang usia para pemimpin sama dengan usia para karyawannya. Hal ini mungkin saja dapat menimbulkan masalah dalam pengambilan keputusan, yang disebabkan oleh sikap, ego dan tingkat emosional keduanya sama. Kemudian untuk latar belakang pendidikan dari pemimpin paling banyak adalah setingkat SLTA, hal ini mempengaruhi pola pikir pemimpin dalam mengambil keputusan dan merancang strategi untuk pencapaian target. Dan Selanjutnya dapat kita lihat bahwa untuk pemimpin pada PT. Sumber Alfaria Trijaya, Tbk Area BSD Tangerang Selatan rata - rata sudah bekerja selama $4-7$ tahun. Hal ini juga dapat menyebabkan seorang pemimpin bersikap otoriter atau mengambil keputusan tanpa berkonsultasi dengan karyawan, karena pemimpin merasa sudah lebih tau dan memahami pekerjaannya dibandingkan dengan karyawan-nya.

Pada saat awal masuk seluruh karyawan harus mengikuti kegiatan pelatihan, dimana pelatihan ini merupakan suatu sarana yang dilakukan oleh perusahaan untuk membangun sumber daya manusia yang handal menuju era persaingan yang semakin ketat, tajam, dan berat. Perusahaan menyadari bahwa pelatihan merupakan fundamental bagi karyawan. Ada tujuan utama program pelatihan dan pengembangan karyawan. Pertama, latihan dan pengembangan dilakukan untuk menutup "gap" antara kecakapan atau kemampuan karyawan dengan permintan jabatan. Kedua, program program tersebut diharapkan dapat meningkatkan efisiensi dan efektivitas kerja karyawan dalam mencapai sasaran-sasaran kerja yang telah ditetapkan. Sekali lagi, meskipun usahausaha ini memakan waktu dan mahal, tetapi akan mengurangi perputaran tenaga kerja dan membuat karyawan menjadi lebih produktif.

Menurut Gomes (2017:197) mendefinisikan pelatihan adalah setiap usaha untuk memperbaiki prestasi kerja pada suatu pekerjaan tertentu yang sedang menjadi tanggung jawabnya. Idealnya, peltihan harus dirancang untuk mewujudkan tujuan-tujuan organisasi, yang pada waktu bersamaan juga mewujudkan tujuan-tujuan para pekerja secara perorangan. Berikut ini adalah data pelatihan karyawan PT. Sumber Alfaria Trijaya, Tbk Area BSD Tangerang Selatan. 
Aldy Baihaqi1 \& Herry Suherman: Pengaruh Gaya Kepemimpinan Dan Pelatihan Terhadap

Produktivitas Kerja Karyawan Pada PT. Sumber Alfaria Trijaya, Tbk Area BSD Tangerang Selatan

Tabel 2. Data pelatihan PT. Alfaria Sumber Trijaya Tbk, area BSD Tangerang Selatan

\begin{tabular}{|c|c|c|c|c|c|}
\hline \multirow{2}{*}{ No } & \multirow{2}{*}{ Indikator } & Jumlah & Persentase & Jumlah & Persentase \\
\hline & & $\mathrm{Ya}$ & $\%$ & Tidak & $\%$ \\
\hline \multirow[b]{2}{*}{1.} & Terkait pengetahuan & & & & \\
\hline & $\begin{array}{l}\text { Pengetahuan karyawan tentang cara } \\
\text { meningkatkan penjualan setelah menerima } \\
\text { pelatihan lebih baik. }\end{array}$ & 20 & $23,52 \%$ & 65 & $76,48 \%$ \\
\hline \multirow[b]{2}{*}{2.} & Terkait Kecakapan & & & & \\
\hline & $\begin{array}{l}\text { Kecakapan karyawan dalam } \\
\text { berkomunikasi dengan customer lebih baik } \\
\text { setelah menerima pelatihan. }\end{array}$ & 40 & $47,06 \%$ & 45 & $52,94 \%$ \\
\hline \multirow[b]{2}{*}{3.} & Kemampuan berpikir & & & & \\
\hline & $\begin{array}{l}\text { Karyawan dapat lebih berinovasi dalam } \\
\text { menawarkan promo yang sedang berlaku. }\end{array}$ & 15 & $17,65 \%$ & 70 & $82,35 \%$ \\
\hline \multirow[b]{2}{*}{4.} & Terkait peningkatan motivasi & & & & \\
\hline & $\begin{array}{l}\text { Karyawan lebih terpacu semangatnya } \\
\text { untuk mencapai target setelah menerima } \\
\text { pelatihan. }\end{array}$ & 10 & $11,77 \%$ & 75 & $88,23 \%$ \\
\hline
\end{tabular}

Sumber : Hasil olah data pra survey (2020)

Dari tabel diatas dapat dilihat bahwa tingkat pengetahuan, kecakapan, kemampuan beripikir, serta peningkatan produktivitas karyawan setelah menerima pelatihan masih sangat kurang. Hal ini dapat disebabkan oleh beberapa faktor seperti metode pelatihan yang kurang tepat, peserta yang kurang antusias dalam menjalani pelatihan, serta pengajar yang kurang dalam memberikan motivasi ketika pelatihan sedang berlangsung.

Dalam hal ini peneliti melihat bahwa apabila ada Gaya Kepemimpinan yang kurang baik ditambah dengan pelatihan yang kurang tepat akan menyebabkan Produktivitas Kerja dari karyawan akan menurun.

Produktivitas merupakan salah satu komponen yang harus dimiliki oleh suatu lembaga atau perusahaan apabila ingin mencapai tujuan yang telah ditetapkan. Dalam kegiatannya organisasi atau perusahaan harus mampu meningkatkan produktivitas dari waktu ke waktu, karena ini menyangkut terhadap kelangsungan perusahaan tersebut. Produktivitas yang baik adalah mampu menunjukkan jumlah pencapaian yang meningkat dan memenuhi kualitas pekerjaan. Disamping itu karyawan juga memiliki kemampuan dalam mengatasi persoalan dalam pekerjaan sehingga mampu menambah daya saing perusahaan secara baik. Hal tersebut selaras dengan teori Simamora (2017:612) berpendapat "Produktivitas kerja merupakan perbandingan antara hasil yang dicapai seseorang dengan target yang ditetapkan dalam waktu tertentu dengan sumber daya yang digunakan".

Berikut data penjualan pada PT. Sumber Alfaria Trijaya, Tbk Area BSD Tangerang Selatan dalam periode Januari - Oktober 2020.

Tabel 3. Data Penjualan Periode Januari - Oktober 2020

\begin{tabular}{lcccc}
\multicolumn{1}{c}{ Toko } & $\begin{array}{c}\text { Jumlah } \\
\text { Karyawan }\end{array}$ & Target & Pencapaian & $\begin{array}{c}\text { Persentase } \\
\text { Pencapaian }\end{array}$ \\
\hline $\begin{array}{l}\text { Buaran Rawa Buntu } \\
2\end{array}$ & 5 & Rp. 3.898.637.656 & Rp. 3.150.600.959 & $80,81 \%$ \\
\hline Cilenggang & 5 & Rp. 3.838.834.332 & Rp. 3.504.890.764 & $91,30 \%$ \\
\hline
\end{tabular}




\begin{tabular}{lcccc}
\hline \multicolumn{1}{c}{ Toko } & $\begin{array}{c}\text { Jumlah } \\
\text { Karyawan }\end{array}$ & Target & Pencapaian & $\begin{array}{c}\text { Persentase } \\
\text { Pencapaian }\end{array}$ \\
\hline Kencana Loka 3 & 6 & Rp. 7.549.334.087 & Rp. 7.109.355.980 & $94,17 \%$ \\
\hline Ciater Barat & 5 & Rp. 5.172.817.867 & Rp. 5.400.634.300 & $104,40 \%$ \\
\hline Kencana Loka 2 & 6 & Rp. 7.274.266.702 & Rp. 6.998.700.568 & $96,21 \%$ \\
\hline Raya Ciater 2 & 5 & Rp. 5.323.427.799 & Rp. 5.638.967.866 & $105,92 \%$ \\
\hline Golden Viena 2 (F) & 6 & Rp. 7.196.241.865 & Rp. 7.200.165.900 & $100,05 \%$ \\
\hline Stasiun Serpong & 6 & Rp. 5.759.731.043 & Rp. 5.078.227.098 & $88,16 \%$ \\
\hline Alam Serpong & 6 & Rp. 5.857.176..884 & Rp. 5.270.340.990 & $89,98 \%$ \\
\hline Raya Cilenggang & 5 & Rp. 4,727,808,760 & Rp. 4.182.636.904 & $88,46 \%$ \\
\hline Pasar Modern & 5 & Rp. 4.544.240.622 & Rp. 4.320.746.062 & $95,08 \%$ \\
\hline Golden Madrid & 5 & Rp. 2.653.225.073 & Rp. 2.076.385.201 & $78,25 \%$ \\
\hline Sta Serpong 2 & 5 & Rp. 2.868.554.508 & Rp. 2.790.667.434 & $97,28 \%$ \\
\hline Ciater Raya & 5 & Rp. 4.115.824.975 & Rp. 4.350.865.078 & $105,71 \%$ \\
\hline Pahlawan Seribu & 5 & Rp. 4.071.186.995 & Rp. 3.998.672.214 & $98,21 \%$ \\
New & 5 & Rp. 915.497 .783 & Rp. 890.390 .890 & $97,25 \%$ \\
\hline BP Ciater & 85 & Rp. 75.396.581.165 & Rp 71.962.248.208 & $1.417,07 \%$ \\
\hline Jumlah & 5 & Rp. 4.712.286.322 & Rp. 4.497.640.513 & $88,56 \%$ \\
\hline Rata - rata & & & & \\
\hline
\end{tabular}

Sumber : Hasil olah data (2020)

Dapat dilihat pada tabel disamping bahwasannya hanya 4 toko saja yang mampu mencapai target dalam periode Januari sampai dengan Oktober 2020. Hal ini menandakan adanya permasalahan pada produktivitas kerja karyawan PT. Sumber Alfaria Trijaya, Tbk Area BSD Tangerang Selatan.

Berdasarkan latar belakang dan uraian yang dikemukakan diatas, maka penulis tertarik menulis penelitian berjudul "Pengaruh Gaya Kepemimpinan dan Pelatihan Terhadap Produktivitas Kerja Pada PT. Sumber Alfaria Trijaya, Tbk Area BSD Tangerang Selatan"

\section{Gaya Kepemimpinan}

Menurut Hasibuan (2017:113) berpendapat "Gaya kepemimpinan adalah cara seorang pemimpin mempengaruhi perilaku bawahan, agar mau bekereja sama dan bekerja secara produktif untuk mencapai tujuan organisasi”. Dia harus mampu membina dan memotivasi bawahannya untuk bekerja sama dan bekerja secara efektif dalam mencapai sasaran perusahaan.

\section{Pelatihan}

Menurut Dessler (2016:323) pelatihan adalah proses mengajarkan karyawan baru atau yang ada sekarang, keterampilan dasar yang mereka butuhkan untuk menjalankan pekerjaan mereka. Sedangkan Hasibuan (2017:7), mendefinisikan pelatihan merupakan suatu usaha peningkatan pengetahuan dan keahlian seorang karyawan untuk mengerjakan suatu pekerjaan tertentu.

Sedangkan menurut Gomes (2017:197) mendefinisikan pelatihan adalah setiap usaha untuk memperbaiki prestasi kerja pada suatu pekerjaan tertentu yang sedang menjadi tanggung jawabnya. Idealnya, peltihan harus dirancang untuk mewujudkan tujuan-tujuan organisasi, yang pada waktu bersamaan juga mewujudkan tujuan-tujuan para pekerja secara perorangan. Pelatihan sering dianggap sebagai aktivitas yang paling umum dan para pimpinan mendukung adanya pelatihan karena melalui pelatihan, para pekerja akan menjadi lebih terampil dan karenanya akan lebih produktif sekalipun manfaat-manfaat tersebut harus diperhitungkan dengan waktu yang tersita ketika pekerja sedang dilatih. 
Aldy Baihaqi1 \& Herry Suherman: Pengaruh Gaya Kepemimpinan Dan Pelatihan Terhadap

\section{Produktivitas Kerja}

Menurut Sutrisno (2016:99) produkivitas adalah hubungan antara keluaran (barangbarang atau jasa) dengan masukan (tenaga kerja, bahan, uang). Produktivitas merupakan ukuran efisiensi produktif. Suatu perbandingan antara hasil keluaran dan masukan. Masukan sering dibatasi dengan tenaga kerja, sedangkan keluaran diukur dalam kesatuan fisik, bentuk, dan nilai. Menurut Sutrisno (2016:101) ada tiga aspek utama yang perlu ditinjau dalam menjamin produktivitas yang tinggi yaitu: Aspek kemampuan manajemen tenaga kerja, Aspek efesiensi tenaga kerja, Aspek kondisi lingkungan pekerjaan.

Ketiga aspek tersebut saling berkaitan dan terpadu dalam suatu sistem dan dapat diukurdengan berbagai ukuran yang relatif sederhana. Produktivitas harus menjadi bagian yang tak boleh dilupakan dalam penyusunan strategi bisnis yang mencakup bidang produksi, pemasaran, keuangan dan bidang lainnya. Sedangkan menurut Anoraga (2016:175) sebagai konsep ekonomis, produktivitas berkenaan dengan usaha atau kegiatan manusia untuk menghasilkan barang atau jasa yang berguna untuk pemenuhan kebutuhan hidup manusia dan masyarakat pada umumnya.

\section{Penelitian Terdahulu}

Penelitian Thamrin dan Irham Subarkah (2018) yang berjudul "Pengaruh Disiplin Kerja Dan Gaya Kepemimpinan Terhadap Produktivitas Kerja Konveksi Famili Jaya Bobotsari Purbalingga Jawa Tengah" diperoleh hasil bahwa disiplin kerja dan gaya kepemimpinan berpengaruh terhadap produktivitas.

Penelitian Endang Kustini, Novita Sari (2020) yang berjudul "Pengaruh Pelatihan Dan Disiplin Kerja Terhadap Produktivitas Kerja Karyawan Pada PT. Bumen Redja Abadi BSD" diperoleh hasil bahwa pelatihan berpengaruh positif dan signifikan terhadap produktivitas kerja karyawan.

Penelitian Yossi Hendriati (2017) yang berjudul "Pengaruh Motivasi Dan Gaya Kepemimpinan Terhadap Produktivitas
Karyawan Pada Pt Cahaya Berlian" diperoleh hasil bahwa motivasi dan gaya kepemimpinan secara parsial berpengaruh signifikan terhadap produktivias kerja karyawan PT. Cahaya Berlian.

Penelitian Kevin M.V. Kaparang, Rosalina A.M. Koleangan, Yantje Uhing (2018) yang berjudul "Pengaruh Gaya Kepemimpinan Dan Pengalaman Kerja Terhadap Produktivitas Kerja Karyawan Pada Pt. Bank Mandiri (Persero) Tbk. Area Manado" diperoleh hasil bahwa bahwa Gaya Kepemimpinan dan Pengalaman Kerja secara bersama simultan berpengaruh positif dan signifikan terhadap Produktivitas Kerja Karyawan.

\section{Kerangka Berfikir}

Menurut Sekaran dalam Sugiyono (2017:60), mennjelaskan bahwa "kerangaka berfikir merupakan model konseptual tentang bagaimana teori berhubungan dengan berbagai faktor yang telah didefinisikan sebagai masalah yang penting". Kerangka berpikir penelitian ini seperti ditunjukkan pada gambar 1 .

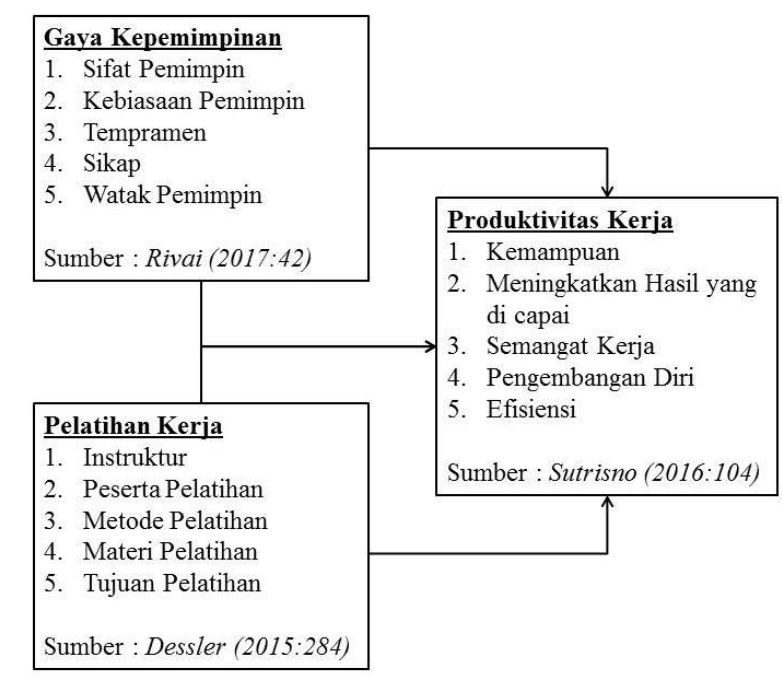

Gambar 1. Kerangka Berfikir Penelitian

\section{Hipotesis}

Hipotesis yang akan dibuktikan dalam penelitian ini :
$\mathbf{H}_{\mathbf{1}}=$ Diduga Terdapat pengaruh yang signifikan antara Gaya kepemimpinan terhadap produktivitas karyawan pada PT. Sumber Alfaria Trijaya Tbk area BSD Tangerang Selatan secara parsial. 


\begin{abstract}
$\mathbf{H}_{\mathbf{2}}=$ Diduga Terdapat pengaruh yang signifikan antara Pelatihan terhadap produktivitas karyawan pada PT. Sumber Alfaria Trijaya Tbk area BSD Tangerang Selatan secara parsial.

$\mathbf{H}_{\mathbf{3}}=$ Diduga Terdapat pengaruh yang signifikan antara Gaya kepemimpinan dan Pelatihan terhadap produktivitas karyawan pada PT. Sumber Alfaria Trijaya Tbk area BSD Tangerang Selatan secara simultan.
\end{abstract}

\section{METODE}

Metode yang digunakan dalam penelitian ini adalah kuantitati dengan teknik analisis menggunakan analisis statistik.
Populasi dalam penelitian ini adalah karyawan PT. Sumber Alfaria Trijaya, Tbk Area BSD Tangerang Selatan yang berjumlah 85 orang . Penentuan sample menggunakan metode sample jenuh yaitu sebanyak 85 orang atau keseluruhan dari jumlah populasi.

\section{HASIL DAN PEMBAHASAN}

\section{Hasil}

\section{Uji Koefisien Korelasi}

Hasil pengujian koefisien korelasi antara variabel gaya kepemimpinan $\left(\mathrm{X}_{1}\right)$ dan variabel pelatihan $\left(\mathrm{X}_{2}\right)$ terhadap variabel Produktivitas Kerja (Y) diperoleh nilai koefisien korelasi ( $r$ ) sebagai berikut ;

Tabel 4 Hasil Uji Koefisien Korelasi

\begin{tabular}{|c|c|c|c|c|}
\hline & & $\begin{array}{c}\text { Gaya } \\
\text { Kepemimpinan }\end{array}$ & Pelatihan & $\begin{array}{l}\text { Produktivitas } \\
\text { Kerja }\end{array}$ \\
\hline \multirow[t]{3}{*}{ Gaya Kepemimpinan } & Pearson Correlation & 1 & $.337^{* *}$ & $.666^{* *}$ \\
\hline & Sig. (2-tailed) & & .002 & .000 \\
\hline & $\mathrm{N}$ & 85 & 85 & 85 \\
\hline \multirow[t]{3}{*}{ Pelatihan } & Pearson Correlation & $.337^{* *}$ & 1 & $.255^{*}$ \\
\hline & Sig. (2-tailed) & .002 & & .018 \\
\hline & $\mathrm{N}$ & 85 & 85 & 85 \\
\hline \multirow[t]{3}{*}{ Produktivitas Kerja } & Pearson Correlation & $.666^{* *}$ & $.255^{*}$ & 1 \\
\hline & Sig. (2-tailed) & .000 & .018 & \\
\hline & $\mathrm{N}$ & 85 & 85 & 85 \\
\hline
\end{tabular}

Sumber : Hasil olah data (2020)

Berdasarkan hasil pengujian pada tabel di atas, diperoleh nilai koefisien korelasi Gaya Kepemimpinan terhadap Produktivitas Kerja Karyawan sebesar 0,666 dimana nilai tersebut berada pada interval 0,60 - 0,799 artinya kedua variabel memiliki tingkat hubungan yang kuat. Nilai koefesian korelasi Pelatihan terhadap Produktivitas Kerja Karyawan diperoleh sebesar 0,255 dimana nilai tersebut berada pada interval 0,20 - 0,399 yang artinya kedua variabel memiliki tingkat hubungan yang lemah.

\section{Regresi Liniear Berganda}

Analisis regresi digunakan untuk melakukan prediksi bagaimana perubahan nilai variabel dependen bila nilai variabel independen dinaikan/diturunkan. Dengan hasil sebagai berikut ;
Tabel 5. Hasil Regresi Liniear Berganda

\begin{tabular}{|c|c|c|c|c|c|c|}
\hline & \multirow[b]{2}{*}{ Model } & \multicolumn{2}{|c|}{$\begin{array}{c}\text { Unstandardized } \\
\text { Coefficients }\end{array}$} & $\begin{array}{l}\text { Standardized } \\
\text { Coefficients }\end{array}$ & \multirow{2}{*}{$\mathrm{t}$} & \multirow{2}{*}{ Sig. } \\
\hline & & B & $\begin{array}{l}\text { Std. } \\
\text { Error }\end{array}$ & Beta & & \\
\hline \multirow[t]{3}{*}{1} & (Constant) & 17.722 & 4.063 & & 4.362 & .000 \\
\hline & $\begin{array}{l}\text { Gaya Kepe- } \\
\text { mimpinan }\end{array}$ & .654 & .087 & .654 & 7.484 & .000 \\
\hline & Pelatihan & .035 & .090 & .034 & .392 & .696 \\
\hline
\end{tabular}

a. Dependent Variable: Produktivitas Kerja

Sumber : Data diolah, 2021

Berdasarkan hasil perhitungan uji regresi berganda yang terdapat pada tabel 5 dapat diketahui persamaan regresi yang terbentuk adalah : $\mathbf{Y}=\mathbf{1 7 . 7 2 2}+\mathbf{0 . 6 5 4}\left(\mathrm{X}_{1}\right)+\mathbf{0 . 0 3 5}\left(\mathrm{X}_{2}\right)$

Persamaan regresi diatas mempunyai arti :

1. Nilai Constant sebesar 17.722, artinya Produktivitas Kerja Karyawan walaupun tanpa dipengaruhi oleh Gaya Kepemimpinan dan Pelatihan sudah mempunyai pengaruh sebesar 17.722 . 
2. Pengaruh variabel Gaya Kepemimpinan terhadap Produktivitas Kerja Karyawan adalah positif. Artinya semakin baik Gaya Kepemimpinan, maka Produktivitas Kerja Karyawan akan meningkat sebesar 0,654.

3. Pengaruh variabel Pelatihan terhadap Produktivitas Kerja Karyawan adalah positif. Artinya semakin tinggi Pelatihan maka Produktivitas Kerja Karyawan akan meningkat sebesar 0,035 .

\section{Koefisien Determinasi}

Uji koefisien determinasi dilakukan untuk mengetahui besar prosentase pengaruh variabel gaya kepemimpinan dan pelatihan terhadap perubahan variabel produktivitas kerja

\section{Tabel 6. Hasil Analisis Koefisien Determinasi} $\left(\mathbf{R}^{2}\right)$

\begin{tabular}{|c|c|c|c|c|}
\hline \multicolumn{5}{|c|}{ Model Summaryb } \\
\hline Model & $\mathrm{R}$ & $\begin{array}{c}\text { R } \\
\text { Square }\end{array}$ & $\begin{array}{c}\text { Adjusted R } \\
\text { Square }\end{array}$ & $\begin{array}{c}\text { Std. Error } \\
\text { of the } \\
\text { Estimate }\end{array}$ \\
\hline 1 &, $667^{\mathrm{a}}$ & ,444 &, 431 & 3,472 \\
\hline
\end{tabular}

a. Predictors: (Constant), Pelatihan, Gaya Kepemimpinan b. Dependent Variable: Produktivitas Kerja

Berdasarkan data tabel di atas, diperoleh nilai R-Square (Koefisien determinasi) sebesar 0,444 hal ini dapat disimpulkan bahwa dan dapat disimpulkan bahwa variabel Gaya Kepemimpinan $\left(\mathrm{X}_{1}\right)$ dan Pelatihan $\left(\mathrm{X}_{2}\right)$ berpengaruh terhadap variabel Produktivitas Kerja (Y) sebesar 44,4\% sedangkan sisanya $55,6 \%$ dipengaruhi oleh faktor lain.

\section{Uji t (Parsial)}

Uji t digunakan untuk menguji koefiesien regresi secara parsial variabel Gaya Kepemimpinan dan Pelatihan terhadap Produktivitas Kerja Karyawan.

Tabel 7. Hasil Uji Parsial

\begin{tabular}{|c|c|c|c|c|c|c|}
\hline & & \multicolumn{2}{|c|}{$\begin{array}{c}\text { Unstandardized } \\
\text { Coefficients }\end{array}$} & $\begin{array}{l}\text { Standardized } \\
\text { Coefficients }\end{array}$ & \multirow{2}{*}{$\mathrm{t}$} & \multirow{2}{*}{ Sig. } \\
\hline & Model & B & $\begin{array}{l}\text { Std. } \\
\text { Error }\end{array}$ & Beta & & \\
\hline \multirow[t]{3}{*}{1} & (Constant) & 17.722 & 4.063 & & 4.362 & .000 \\
\hline & $\begin{array}{l}\text { Gaya Kepe- } \\
\text { mimpinan }\end{array}$ & .654 & .087 & .654 & 7.484 & .000 \\
\hline & Pelatihan & .035 & .090 & .034 & .392 & .696 \\
\hline
\end{tabular}

a. Dependent Variable: Produktivitas Kerja Sumber : Data diolah, 2021

Berdasarkan hasil uji t diatas :

Dari tabel diatas, diperoleh nilai $t_{\text {hitung }}$ sebesar 7,484 sedangkan nilai tabel untuk $n=82$ sebesar 1,989. Karena nilai $t_{\text {hitung }}>t_{\text {tabel }}$ dan nilai taraf signifikan $(\alpha)$ sebesar $0,000<0,05$, maka $\mathrm{H}_{0}$ ditolak dan $\mathrm{H}_{1}$ diterima. Sehingga dapat disimpulkan bahwa "Terdapat pengaruh yang signifikan antara Gaya Kepemimpinan terhadap Produktivitas Kerja Karyawan PT. Sumber Alfaria Trijaya, Tbk Area BSD Tangerang Selatan".

Dari tabel diatas, diperoleh nilai $t_{\text {hitung }}$ sebesar 0,392 sedangkan nilai $t_{\text {tabel }}$ untuk $\mathrm{n}=82$ sebesar 1,989. Karena nilai $t_{\text {hitung }}<t_{\text {tabel }}$ dan nilai taraf signifikan $(\alpha)$ sebesar $0,696>0,05$, maka $\mathrm{H}_{2}$ ditolak dan $\mathrm{H}_{0}$ diterima. Sehingga dapat disimpulkan bahwa " Tidak Terdapat pengaruh yang signifikan antara Pelatihan terhadap Produktivitas Kerja Karyawan Pada PT. Sumber Alfaria Trijaya, Tbk Area BSD Tangerang Selatan".

\section{Uji F (Simultan)}

Uji simultan digunakan untuk mengetahui pengaruh variabel bebas secara bersama-sama terhadap variabel terikat.

Tabel 8. Hasil Uji F (Simultan)

ANOVA $^{\mathrm{a}}$

\begin{tabular}{|c|c|c|c|c|c|c|}
\hline \multicolumn{2}{|c|}{ Model } & $\begin{array}{l}\text { Sum of } \\
\text { Squares }\end{array}$ & Df & \multicolumn{2}{|l|}{ Mean } & Sig. \\
\hline 1 & Regression & 790.746 & 2 & 395.373 & 32.806 & $.000^{\mathrm{b}}$ \\
\hline & Residual & 988.266 & 82 & 12.052 & & \\
\hline & Total & 1779.012 & 84 & & & \\
\hline
\end{tabular}

a. Dependent Variable: Produktivitas Kerja

b. Predictors: (Constant), Pelatihan, Gaya Kepemimpinan Sumber : Data diolah, 2021

Dari tabel di atas, dapat dilihat nilai $\mathrm{F}_{\text {hitung }}$ adalah sebesar 32,806 dengan nilai signifikan $\mathrm{F}$ sebesar 0,000. Pengujian akan menolak H0 jika p-value $<\alpha$. Jika dibandingkan dengan taraf signifikan $\alpha=5 \%$ maka p-value $(0,000)$ bernilai lebih kecil dari $\alpha$ sehingga $\mathrm{H} 0$ ditolak dan $\mathrm{H} 3$ diterima. Serta hasil pengujian pengaruh simultan variabel bebas terhadap variabel terikatnya diperoleh nilai $\mathrm{F}_{\text {hitung }}=32,806>$ nilai $\mathrm{F}_{\text {tabel }}=3,11$, sehingga $\mathrm{HO}$ ditolak dan $\mathrm{Ha}$ diterima. Sehingga dapat disimpulkan bahwa 
terdapat pengaruh yang signifikan antara Gaya Kepemimpinan dan Pelatihan terhadap Produktivitas Kerja Karyawan Pada PT. Sumber Alfaria Trijaya, Tbk Area BSD Tangerang Selatan.

\section{Pembahasan}

Hasil uji pengaruh variabel Gaya Kepemimpinan (X1) Terhadap Produktivitas Kerja Karyawan $(\mathrm{Y})$ diperoelh thitung $=7,484$ sedangkan $t_{\text {tabel }}=1,989$ dengan taraf signifikan $0,000<0,05$ maka Terdapat pengaruh yang signifikan antara Gaya Kepemimpinan terhadap Produktivitas Kerja Karyawan

Hasil uji pengaruh Variabel Pelatihan (X2) Terhadap Produktivitas Kerja Karyawan (Y) diperoleh nilai uji thitung $=0,392$ sedangkan $\mathrm{t}_{\text {tabel }}=1,989$ dengan taraf signifikan 0,696 > 0,05 maka dapat disimpulkan bahwa tidak terdapat pengaruh yang signifikan antara Pelatihan terhadap Produktivitas Kerja Karyawan

Hasil pengaruh simultan Variabel Gaya Kepemimpinan (X1) dan Pelatihan (X2) Terhadap Produktivitas Kerja Karyawan (Y) diperoleh $\mathrm{F}_{\text {hitung }}$ sebesar 32,806 > Ftabel 3,11 dengan tingkat sigifikan sebesar $0,000<0,05$. Dapat diartikan terdapat pengaruh positif dan signifikan antara Gaya Kepemimpinan dan Pelatihan terhadap Produktivitas Kerja Karyawan secara simultan.

\section{SIMPULAN}

Secara parsial bahwa pengaruh Gaya Kepemimpinan terhadap Produktivitas Kerja Karyawan dapat diketahui dalam nilai $t_{\text {hitung }}$ dari variabel Gaya Kepemimpinan sebesar thitung $(7,484>1,98932)$ dan nilai signifikansinya $0,000<0,05$. Maka dapat ditarik kesimpulan bahwa variabel Gaya Kepemimpinan berpengaruh signifikan terhadap Produktivitas Kerja Karyawan.

Secara parsial bahwa pengaruh Pelatihan terhadap Produktivitas Kerja Karyawan dapat diketahui dalam nilai $t_{\text {hitung }}$ dari variabel Pelatihan sebesar nilai thitung $(0,392<1,98932)$ dan nilai signifikansinya $0,083>0,05$. Maka dapat ditarik kesimpulan bahwa variabel Pelatihan tidak berpengaruh signifikan terhadap Produktivitas Kerja Karyawan.

Hasil pengujian pengaruh simultan variabel bebas terhadap variabel terikatnya diperoleh nilai $\mathrm{F}_{\text {hitung }}=32,806>$ nilai $\mathrm{F}_{\text {tabel }}=$ 3,11, sehingga $\mathrm{H}_{0}$ ditolak dan $\mathrm{H}_{\mathrm{a}}$ diterima. Sehingga dapat disimpulkan bahwa terdapat pengaruh yang signifikan antara Gaya Kepemimpinan dan Pelatihan terhadap Produktivitas Kerja Karyawan.

\section{DAFTAR PUSTAKA}

Abdullah, (2017). Etika pendidikan. Talang Jambi: PT. Raja Grafindo.

Ardana, I Komang dkk. (2017) Manajemen Sumber Daya Manusia. Yogyakarta: Graha ilmu.

Arikunto, Suharsimi (2014). Prosedur Penelitian Suatu Pendekatan Praktek. Jakarta: Rineka Cipta.

Cecep Mohamad Kapi (2017). Pengaruh Gaya Kepemimpinan ,Koordinasi Dan Disiplin Kerja Terhadap Produktivitas Kerja Pegawai Pt. Pos Indonesia Tasikmalaya. Jurnal Bisnis, Keuangan Dan Komputer ISSN : 2549-9824 Vol. 1 No. 1 Maret 2017.

D. Sunarsi (2018). Pengaruh Rekrutmen, Seleksi Dan Pelatihan Terhadap produktivitas Kerja Karyawan. J. KREATIF, Vol. 6, No. 1, ISSN : 2339 0689, E-ISSN : 2406-8616 (14 - 31).

Edi Sutrisno (2016). Manajemen Sumber Daya Manusia. Jakarta: Prenadamedia Group.

Edi Sutrisno (2017). Manajemen Sumber Daya Manusia. Jakarta: Prenadamedia Group.

Endang. K, Novita. S, Dosen Fakultas Ekonomi Universitas Pamulang, Alumni Universitas Pamulang (2020). Pengaruh Pelatihan Dan Disiplin Kerja Terhadap Produktivitas Kerja Karyawan Pada PT. Bumen Redja Abadi - BSD. JENIUS. Vol. 3, No. 3, E - ISSN : 2598 - 9502 P - ISSN : 2581 - 2769. 
Feriyanto, Andri dan Shyta, Endang Triana.

2015. Pengantar Manajemen (3 in 1).

Kebumen: Mediatera.

Gerry Dessler (2016) Human Resources Management, Prenticehall, London: International Inc.

Gomes, Faustino Cardoso (2016) Manajemen Sumber Daya Manusia. Jakarta: Andi Offset.

Handoko (2016) Manajemen Personalia dan Sumberdaya Manusia. Yogyakarta: BPFE.

Hasibuan, Malayu S.P. (2017). Manajemen Sumber Daya Manusia. Edisi Revisi. Jakarta: PT Bumi Aksara.

Imam Ghozali (2017). Aplikasi Analisis Multivariate Dengan Program SPSS. Edisi Kelima. Semarang: Badan Penerbit Undip.

Kevin M.V. Kaparang, Rosalina A.M. Koleangan, Y. Uhing (2018). Pengaruh Gaya Kepemimpinan Dan Pengalaman Kerja Terhadap Produktivitas Kerja Karyawan Pada Pt. Bank Mandiri (Persero) Tbk. Area Manado. Jurnal EMBA Vol.6 No.4 September 2018, Hal. 3743 - 3752 ISSN 2303-1174.

M. Yona, A. Wulandari (2020). Pengaruh Gaya Kepemimpinan, Pelatihan Dan Program Keselamatan Dan Kesehatan Kerja Terhadap Produktifitas Kerja Karyawan Pt. Ersyah Sejati. Jurnal Bening Prodi Manajemen Universitas Ria Kepulauan Batam Volume 7 No. 1 Tahun 2020 PISSN 2252-5262 E-ISSN 2614-499.

Mangkunegara, Prabu Anwar. (2017). Evaluasi Kinerja SDM. Cetakan ke tujuh, Bandung: PT Refika Aditama.

Oemar Hamalik (2015) Manajemen Pengembangan Manajemen, Bandung: PT. Remaja Rosda Karya.

Panji Anoraga (2017) Psikologi Kerja, Jakarta: Rineka Cipta. Pendidikan. Jakarta: Bumi Aksara.

Rivai Veithzal (2017) Manajemen Sumber Daya Manusia Untuk Perusahaan. Jakarta: PT Raja Grafindo Persada.
Robbins, Stephen. P. dan Mary Coulter. (2017) Manajemen. Jakarta: PT. Indeks Kelompok Gramedia.

S. Martono, M. Aspiyah (2016). Pengaruh Disiplin Kerja, Lingkungan Kerja, Dan Pelatihan terhadap Produktivitas Kerja Pada Cv. Lut Putra Solder. Management Analysis Journal 5 (4) ISSN 2252-6552.

Salam, Burhanuddin. (2016). Pengantar Filsafat. Jakarta: Bumi Aksara

Santoso, Singgih (2015). Menguasai Statistik Multivariat. Jakarta: PT Elex Media Komputindo.

Sedarmayanti (2016) Manajemen Sumber Daya Manusia, Reformasi Birokrasi dan Manajemen Pegawai Negeri Sipil, Cetakan Kelima, Bandung: PT Refika Aditama.

Sedarmayanti. (2017). Sumber Daya Manusia dan Produktivitas Kerja. Jakarta: Mandar Maju.

Sudjana. (2005). Metode Statistika. Bandung: Tarsito

Sugiyono (2017), Metode Penelitian Administrasi: dilengkapi dengan Metode $R \& D$, Bandung: Alfabeta.

Thamrin dan I. Subarkah (2018). Pengaruh Disiplin Kerja Dan Gaya Kepemimpinan Terhadap Produktivitas Kerja Konveksi Famili Jaya Bobotsari Purbalingga Jawa Tengah. Jurnal Disrupsi Bisnis, Vol. 1, No.1, Juli, ISSN 2621 - 797X.

Ubaid. A. F , Amin Kuneifi E. F, Herry. S (2017). Pengaruh Gaya Kepemimpinan Dan Disiplin Kerja Terhadap Produktivitas Kerja Karyawan Pt. Caraka Pilar Mandiri. PEKOBIS Jurnal Pendidikan, Ekonomi dan Bisnis Vol. 2 No. 3, P- ISSN: 2503- 5142 E- ISSN: 2686- 3235 .

Yossi Hendriati (2017). Pengaruh Motivasi Dan Gaya Kepemimpinan Terhadap Produktivitas Karyawan Pada Pt Cahaya Berlian. Journal of Economy, Business and Accounting (COSTING) Volume 1 No 1, Desember 2017 e-ISSN : 2597 5234. 